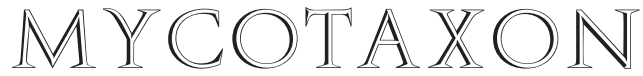

Volume 118, pp. 455-458

http://dx.doi.org/10.5248/118.455

\title{
Validation of combinations with basionyms published by Fries in 1861
}

\section{Scott A. Redhead ${ }^{1^{*}}$, Joseph F. Ammirati ${ }^{2}$, Lorelei L. Norvell ${ }^{3}$, Alfredo Vizzini ${ }^{4} \&$ Marco Contu $^{5}$}

${ }^{1}$ National Mycological Herbarium, Eastern Cereal \& Oilseed Research Centre C.E.F., Agriculture \& Agri-Food Canada, Ottawa, Ontario, Canada, K1A 0C6

${ }^{2}$ Department of Biology, 351330, University of Washington, Seattle, WA 98195 USA

${ }^{3}$ Pacific Northwest Mycology Service,

6720 NW Skyline Boulevard, Portland, OR 97229-1309 USA

${ }^{4}$ Dipartimento di Biologia Vegetale, Università degli Studi di Torino,

Viale Mattioli 25, I-10125, Torino, Italy

${ }^{5}$ Via Marmilla, 12 (I Gioielli 2), I-07026 Olbia (OT), Italy

*Correspondence to: scott.redhead@agr.gc.ca

Abstract - Authors (including some of us) have incorrectly cited as basionyms names treated by Fries in 1863 that were actually originally published by him in 1861. As these basionym citation errors mean that the intended new combinations are not validly published, the following combinations are again proposed as new: Chromosera cyanophylla, Mythicomyces corneipes, Tephrocybe misera, T. tesquorum. Three other intended combinations are noted as also not validly published, but the species are currently treated under the different (and validly published) names Haasiella venustissima, Phaeoclavulina curta, and Rhodonia placenta.

Key words - Ceriporiopsis, Gerronema, Ramaria, International Code of Botanical Nomenclature

\section{Introduction}

Fries (1861) published a series of observations on new or little known hymenomycetes from Sweden. Most of his new taxa were included again under the same names in his Monographia Hymenomycetum Sueciae (Fries 1863). In his subsequently published HymenomyCETEs EuropaEI (Fries 1874), Fries referred back only to the 1863 publication for each of the names originally published in 1861 . This has led to a series of citation errors by later authors and indices, some of which affect the valid publication of proposed combinations. 
In 1863, Fries did refer back to the 1861 publication as the source for each of the names corrected below. Therefore the authors, who proposed the new combinations after 1 January 1953 and who cited only the 1863 or later publications, violated Articles 33.4 and 33.7 of the InTERnational Code of Botanical Nomenclature (McNeill et al. 2006) and did not validly publish their new combinations.

Under Art. 33.5 \& 33.7(a), such citation errors are not correctable. Here we validate the previously proposed binomials that are now generally accepted and in current use, despite their current lack of status under the Code (McNeill et al. 2006). With one exception in Haasiella, we are unaware of incidental subsequent validations.

Chromosera cyanophylla (Fr.) Redhead, Ammirati \& Norvell, comb. nov.

MycoBank MB 563787

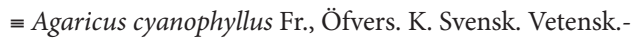

Akad. Förhandl. 18(1): 23 (1861).

Redhead et al. (1995) proposed the genus Chromosera Redhead, Ammirati \& Norvell, citing as type "Chromosera cyanophylla" and listing Fries (1863) (and not the earlier Fries 1861) for the basionym. They did, however, list as obligate synonyms three validly published names: Agaricus cyanophyllus Fr. (albeit with the incorrect citation), Omphalia cyanophylla (Fr.) Quél. (Quélet 1872: 99), and Omphalina cyanophylla (Fr.) Quél. (Quélet 1886: 45). This indication of the type fulfilled the requirements for valid publication of the generic name (Art. 37.2), but the incorrect citation did not meet the requirements for valid publication of the binomial. Notably, the requirements for valid publication of new combinations prior to 1953 were far more lenient.

Mythicomyces corneipes (Fr.) Redhead \& A.H. Sm. comb. nov.

MycoBank MB 563788

$\equiv$ Agaricus corneipes Fr., Öfvers. K. Svensk. Vetensk.-Akad. Förhandl. 18(1): 25 (1861).

Similarly, Redhead \& Smith (1986) proposed the genus Mythicomyces Redhead \& A.H. Sm., citing as type "Mythicomyces corneipes (Fries) comb. nov." They listed as obligate synonyms two validly published names: the first, Agaricus corneipes Fr., incorrectly cited Fries (1863), and the second was Psilocybe corneipes (Fr.) P. Karst. (Karsten 1879: 504). These actions fulfilled the requirements for valid publication of the generic name (Art. 37.2) but failed to meet requirements for valid publication of the binomial, and so we publish it here.

Tephrocybe misera (Fr.) M.M. Moser ex Contu \& Vizzini comb. nov. MycoBank MB 563789

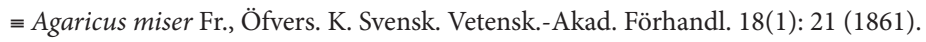


Tephrocybe tesquorum (Fr.) M.M. Moser ex Contu \& Vizzini, comb. nov.

MrcoBank MB 563790

= Agaricus tesquorum Fr., Öfvers. K. Svensk. Vetensk.-Akad. Förhandl. 18(1): 22 (1861).

Moser (1967) proposed two combinations in Tephrocybe but cited Fries (1863) rather than (1861).

\section{Notes on other cases of names not being validly published}

Haasiella venustissima (Fr.) Kotl. \& Pouzar ex Chiaffi \& Surault, Bull. Soc. Mycol.

Fr. 112: 127 (1996).

„ Agaricus venustissimus Fr., Öfvers. K. Svensk. Vetensk.-

Akad. Förhandl. 18(1): 21 (1861).

Kotlaba \& Pouzar (1966) erected the genus Haasiella Kotl. \& Pouzar, typified by $H$. splendidissima Kotl. \& Pouzar, and included a second species, for which they proposed the combination "Haasiella venustissimus," citing Fries (1863) for the basionym. Their combination was inadvertently validated by Chiaffi \& Surault (1996), who cited the basionym and correct place of publication. The proposed combination "Gerronema venustissimum" by Singer (1962) is not validly published, as only Fries (1863) was cited.

Phaeoclavulina curta (Fr.) Giachini, Mycotaxon 115: 190 (2011).

三 Clavaria curta Fr., Öfvers. K. Svensk. Vetensk.-Akad. Förhandl. 18(1): 31 (1861).

The intended combination in Ramaria by Schild (1994) was not validly published because he referred only to Fries (1863) "Monogr. Hym. Suec.", which he mistakenly cited as "1857," the date of the earlier parts of that title. Giachini \& Castellano (2011) correctly cited Fries (1861).

Rhodonia placenta (Fr.) Niemelä, K.H. Larss. \& Schigel, Karstenia 45(2): 79 (2005). $\equiv$ Polyporus placenta Fr., Öfvers. K. Svensk. Vetensk.-Akad. Förhandl. 18(1): 30 (1861).

Domański’s (1963) intended combination in Ceriporiopsis Domański, where he cites Fries (1874), was not validly published. Niemelä et al. (2005) correctly cited Fries (1861).

\section{Acknowledgements}

We thank Shaun Pennycook and John McNeill for reviewing the manuscript and confirming that the genus Chromosera was validly published according to the ICBN even though the earlier combination of Chromosera cyanophylla was not validly published.

\section{Literature cited}

Chiaffi M, Surault J-L. 1996. Une espèce rare et remarquable, Haasiella venustissima (Fr.) Kotl. \& Pouz. Bull. Soc. Mycol. France 112: 127-135.

Domański S. 1963. Dwa nowe rodzaje grzybów z grupy “Poria Pers. ex S.F. Gray”. Acta Soc. Bot. Poloniae 32: 731-739. 
Fries EM. 1861. Hymenomycetes novi vel minus cogniti, in Suecia 1852-1860 observati. Öfvers. K. VetenskAkad. Förh. 18(1): 19-34.

Fries EM. 1863. Monographia Hymenomycetum Sueciae 2: [147]-355. Uppsala, CA Leffler.

Fries EM. 1874. Hymenomycetes Europaei sive Epicriseos systematis mycologici. Editio altera. Upsaliae, E. Berling.

Giachini, AJ, Castellano MA. 2011. A new taxonomic classification for species in Gomphus sensu lato. Mycotaxon 115: 183-201. http://dx.doi.org/10.5248/115.183

Karsten PA. 1879. Rysslands, Finlands och den Skandinaviska halföns Hattsvampar. Förra Delen: Skifsvampar. Bidr. Känn. Finl. Nat. Folk 32. XXVIII + 571 p.

Kotlába F, Pouzar Z. 1966. Haasiella, a new agaric genus and H. splendidissima sp. nov. : Ceská Mykologie 20: 135-140.

McNeill J, Barrie FF, Burdet HM, Demoulin V, Hawksworth DL, Marhold K, Nicolson DH, Prado J, Silva PC, Skog JE, Wiersema J, Turland NJ (eds.) 2006. International code of botanical nomenclature (Vienna Code). Adopted by the Seventeenth International Botanical Congress Vienna, Austria, July 2005. Reg. Veget. 146: i-xvi, 1-568.

Moser M. 1967. Basidiomyceten II. Teil. Die Röhrlinge und Blätterpilze (Agaricales). Kleine Kryptogamenflora, ed. 3, IIb/2. 443 p.

Niemelä T, Kinnunen J, Larsson K-H, Schigel DD, Larsson E. 2005. Genus revisions and new combinations of some North European polypores. Karstenia 45: 75-80.

Quélet L. 1872. Les champignons du Jura et des Vosges. Mém. Soc. Emul. Montbéliard, sér. II, 5: 43-332.

Quélet L. 1886. Enchiridion fungorum in Europa media et prasertim in Gallia vigentium. Lutetiae. $352 \mathrm{p}$.

Redhead SA, Smith AH. 1986. Two new genera of agarics based on Psilocybe corneipes and Phaeocollybia perplexa. Canad. Jour. Bot. 64: 643-647. http://dx.doi.org/10.1139/b86-082

Redhead SA, Ammirati JF, Norvell LL. 1995. Omphalina sensu lato in North America 3: Chromosera gen. nov. Beih. Sydowia 10: 155-167.

Schild E. 1994. Ramaria-Studien Clavaria curta Fries (1857) eine eigene Art. Z. Mykol. 60: 123-130. Singer R. 1962 (1961). Diagnoses fungorum novorum Agaricalium II. Sydowia 15: 45-83. 